\title{
Effect of rosette size, clonality and spatial distribution on the reproduction of Vriesea carinata (Bromeliaceae) in the Atlantic Forest of Paraná, southern Brazil
}

\author{
Marcelo Aparecido de Souza Silva, ${ }^{1,2}$ and Isabela Galarda Varassin ${ }^{3, *}$
}

Received: April 26, 2016

Accepted: July 05, 2016

\begin{abstract}
Plant size and clonality are important traits for explaining the reproductive effort of clonal plants. Larger plants can invest more resources into reproduction, and clonality is known to increase reproductive effort. Moreover, reproductive effort is influenced by environmental variation, and so the spatial distribution of plants may affect plant reproductive effort. We investigated the effect of plant size, clonality and spatial distribution on the reproductive effort of Vriesea carinata in the Atlantic Forest in the state of Paraná, Brazil. We marked twenty individual plants and measured their rosette size, biomass and number, as well as rosette reproductive effort (number of flowers, fruits and seeds). We also evaluated the relationship between reproductive effort and spatial distribution of plants. Reproductive effort did not correlate with size, whereas greater clonal growth contributed to a lower reproductive effort because rosettes within clones that had more rosettes set fewer flowers. We found that plants growing closer to each other exhibited similar reproductive efforts independently of vegetative traits, because reproductive traits were spatially autocorrelated. In Vriesea carinata, the main drivers of reproductive effort are clonality, which decreases flower production, and spatial factors, which result in greater similarity in reproductive efforts among more proximate plants.
\end{abstract}

Keywords: clonal growth, morphological variation, reproductive effort, RNSM, Vriesea

\section{Introduction}

Plant size and biomass are correlated with the allocation of resources for reproduction (Aarssen \& Taylor 1992), and thus are important for plant fitness (Bazzaz 1997). Resource allocation for reproduction is defined as the proportion of resources, such as energy or biomass, invested by a plant in vegetative structures versus those invested in reproductive structures, such as flowers, fruits, seeds, floral stems and bracts (Abrahamson \& Caswell 1982; Bazzaz et al. 1987). Flowers, fruits, and seeds are obvious reproductive parts of plants, but other structures, such as floral stems and bracts, may also be involved in resource allocation (Bazzaz 1997). The amount of resources invested in reproduction is closely correlated with plant size and biomass, such that bigger/heavier plants invest more in flowering than smaller plants (Aarssen \& Taylor 1992). For bromeliads, the amount of resources invested in reproductive structures is also correlated with the size of the plant, but not always proportionally (Mantovani \& Iglesias 2009).

A combination of sexual reproduction, via seed production (Martinelli 1997), and vegetative reproduction,

\footnotetext{
${ }^{1}$ Pós-graduação em Conservação da Natureza e Educação Ambiental, Pontifícia Universidade Católica do Paraná, 80215-901, Curitiba, PR, Brazil

${ }^{2}$ Associação Franciscana de Ensino Senhor Bom Jesus, Nestor Victor, 910, 82620400, Curitiba, PR, Brazil

${ }^{3}$ Departamento de Botânica, Universidade Federal do Paraná, 81531-980, Curitiba, PR, Brazil

${ }^{*}$ Corresponding author: isagalarda@gmail.com
} 
via clonal propagation, is common among bromeliads (Benzing 2000). Clonal reproduction assures the persistence of local populations by skipping sterility or a lack of pollinators (Reitz 1983; Sampaio et al. 2002). In clonal plants, parental and daughter ramets are physiologically integrated (Pitelka \& Ashmun 1985), which results in the transfer of resources that improves clonal growth and survival (Roiloa et al. 2010). Clonality, in turn, may also increase flower production (Demetrio et al. 2014).

In bromeliads, the spatial distribution of plants affects their sexual reproductive success (Scrok \& Varassin 2011). The spatial distribution of bromeliads can be influenced by the local environment, including such factors as the presence of suitable substrate, light, temperature and humidity (Cogliatti-Carvalho et al. 2001). These environmental features are often spatially structured (Cottenie 2005) and may influence plant reproduction in a complex way. For example, neighboring individuals may compete for pollinators (Grindeland et al. 2005; Brys \& Jacquemyn 2010), and so changes in fecundity may be related to variation in spatial arrangement (Aarssen \& Taylor 1992; Scrok \& Varassin 2011). Furthermore, the balance between clonal and sexual growth in clonal plants may change according to microenvironmental heterogeneity (Coelho et al. 2008a; Izquierdo \& Piñero 1998). Considering that neighboring individuals are under the same microenvironmental conditions, the balance between clonal and sexual growth would be expected to be similar. Therefore, it is expected that neighboring individuals would be similar in terms of morphology, reproduction (Jacquemyn \& Honnay 2008) and/or kinship (Kittelson \& Maron 2000). If so, this would be reflected in a spatial autocorrelation between these traits.

Reproductive traits for both pollination and dispersal are considered important drivers of the diversification of Bromeliaceae (Givnish et al. 2014). These traits are associated with an epiphytic habitat and include: 1) sexual reproduction coupled with bird-pollination (mostly hummingbirds) and 2) presence of "entangling seeds" (i.e., those able to attach to a host), such as wind-dispersed comose seeds or animaldispersed seeds from fleshy fruits. Vriesea is the third largest bromeliad genus with approximately 280 species (Costa et al. 2015), which have monocarpic and clonal reproduction via axillary buds in the basal leaf sheaths (Costa et al. 2014), and are mostly pollinated by hummingbirds (Araújo et al. 1994; Sazima et al. 1995a; 1996; Martinelli 1997; Machado \& Semir 2006; Varassin \& Sazima 2012), but also by bats (Sazima et al. 1995b; 1999; Martinelli 1997; Kaehler et al. 2005), bees (Kaehler et al. 2005) and butterflies (Scrok \& Varassin 2011; Varassin \& Sazima 2012). The comose seeds are dispersed by wind (Costa et al. 2015).

Our study model was Vriesea carinata Wawra, which occurs in the Atlantic Forest of Paraná in southern Brazil. We hypothesized that size and clonality are important traits for explaining the reproductive effort (number of flowers, fruits and seeds) of this bromeliad. We also hypothesized that due the fact that environmental variation is often spatially structured, the spatial distribution of plants will explain reproductive effort in $V$. carinata. The following questions guided our study: 1 ) Does rosette size increase sexual reproductive effort in $V$. carinata? 2) Does clonal growth (number of rosettes) increase sexual reproductive effort in V. carinata? 3) Will plants distributed more closely have similar sexual reproductive effort?

\section{Materials and methods}

\section{Study site}

We carried out this study at Reserva Natural Salto Morato (hereafter RNSM), which belongs to Fundação Grupo Boticário de Proteção à Natureza (FGBPN). It is located in Guaraqueçaba in the state of Paraná of southern Brazil within a broader conservation unit, the Environmental Protection Area of Guaraqueçaba ( $25^{\circ} 10^{\prime} 44^{\prime \prime}$, $\left.48^{\circ} 18^{\prime} 42^{\prime \prime} \mathrm{W}\right)$. RNSM encompasses 2,340 ha of Atlantic Forest and varies in elevation from 15 to $918 \mathrm{~m}$. According to the Koeppen system, the climate of the region is Af - tropical super humid without drought, with an average annual temperature of $21^{\circ} \mathrm{C}$ and average monthly temperatures ranging between 17 and $25^{\circ} \mathrm{C}$. The summer (November to March) is warm and rainy, whereas the winter is dry and cold (FGBPN 2011).

Fieldwork was carried out from June to August 2012, when we selected and marked 20 individual plants of Vriesea carinata Wawra close to a trail in the reserve (ca. 25⒈ $18^{\prime \prime}$ 'S, 48³0’72"W).

\section{Plant species}

Vriesea carinata Wawa is usually an epiphytic bromeliad. It occurs in humid and well-preserved sites (Martinelli et al. 2008), and has a broad distribution in the Atlantic Forest, occurring from the state of Rio Grande do Sul to the states of Minas Gerais and Espírito Santo (Forzza et al. 2016). It flowers from April to October, with a peak from June to August, has flowers of various shades of red (Smith \& Downs 1977; Wanderley \& Martins 2007; Martinelli et al. 2008) with each rosette producing a single inflorescence. Anthesis occurs from 07:30 to 17:00, and lasts a single day (Araújo et al. 1994; Machado \& Semir 2006; Piacentini \& Varassin 2007). At the study site, Vriesea carinata is pollinated by hummingbirds (Piacentini \& Varassin 2007).

Individuals of $V$. carinata at the study site have one to five rosettes (pers. obs.). Clonal growth can be visually followed by the growth of axillary buds at basal leaf sheaths of the parent plant. The shoots are born outside the rosettes, and produce clumps of rosettes. Following the order of axillary shoots, rosette age hierarchy, from the oldest to the youngest daughter rosettes, was determined by the order of sexual maturity. Rosettes linked by stolons were considered ramets 
of the parent plant (genet). Therefore the individual can be either an isolated rosette or groups of rosettes linked by stolons. In our study, we considered the plants as different individuals when they were: i) not linked by stolons, ii) at least two meters apart and iii) on different tree trunks. A voucher was deposited at the Museu Botânico Municipal de Curitiba (voucher number 390642).

\section{Sexual reproductive effort}

For each plant we selected a single rosette, the oldest one, to estimate sexual reproductive effort. For that rosette we measured inflorescence length and counted the total number of flowers, total number of fruits, and the number of seeds per fruit. The number of fruits produced by the rosette was counted until the end of the flowering period in August. To estimate seed number we sampled three fruits from a single rosette from each individual plant: one fruit from the base of the infructescence, one from the middle and one from the apex. Since the seeds are very small and abundant, we estimated the number produced in each of the three fruits based on the mass of 20 seeds and extrapolated to the total mass of the fruit. The seeds were weighed on an analytical scale with $0.001 \mathrm{~g}$ accuracy.

\section{Rosette size, clonality and spatial distribution}

We measured rosette size in two ways: 1) diameter of each rosette from the most extreme leaf (apex) on one side to the most extreme leaf (apex) on the opposite side; and 2 ) length of the most basal leaf. The rosettes, composed of leaves and inflorescence, were dried for $96 \mathrm{~h}$ at $60^{\circ} \mathrm{C}$ and subsequently weighted on an analytical balance.

Since Vriesea carinata may have one to five rosettes, we marked plants with different levels of clonal growth or clonality (estimated here as the number of rosettes); four plants had isolated rosettes (one rosette), four plants had two rosettes, four had three rosettes, four had four rosettes and four had five rosettes (totaling 20 plants). All plants were georeferenced using a high precision 62 s model GPS; plants were at least two meters apart to avoid georeferencing error as indicated by the GPS manual.

\section{Data analysis}

To test if larger size is related to an increase in sexual reproductive effort, we used a partial correlation analysis between vegetative traits (rosette diameter, basal leaf length and biomass) and reproductive traits (inflorescence length, number of flowers, fruits, and seeds).

To test if increased clonality (plants with more rosettes) is related to an increase in sexual reproductive effort, we analyzed the relationship between the level of clonal growth and reproductive traits (inflorescence length, number of flowers/rosette, fruits/rosette and seeds/fruit) with a regression analysis. Since the number of fruits was correlated with the number of flowers produced by each rosette $(r 2=0.68 ; F 1,18=41.51 ; P<0.0001)$, we used the regression residuals between those two variables to test the effect of the number of rosettes on the number of fruits, controlled by the number of flowers.

To analyze whether reproductive effort is related to spatial distribution, that is to test for the presence of spatial autocorrelation in our data, we performed a Mantel test (Mantel 1967; Legendre \& Fortin 1989). We first used a Mantel correlation between the matrix of vegetative variables and the spatial matrix to test whether vegetativeley similar plants grew closer to each other, possibly due to a kinship or dispersal effect. We tested for spatial autocorrelation in reproduction traits with a partial Mantel correlation using the Pearson coefficient. In the Mantel test, we compared the reproductive data matrix (number of flowers, fruits, and seeds) to the spatial data matrix (latitude and longitude transformed into geodesic distances), and used the vegetative data matrix (number of rosettes, diameter, basal leaf length, and dry biomass weight) as a control for rosette size. The matrix of vegetative variables was standardized and the matrix of reproductive variables was log-transformed. We converted all matrices to dissimilarity matrices, using the Euclidean distance for the matrix of latitude and longitude and the matrix of vegetative variables, and the Bray-Curtis distance for the matrix of reproductive variables. We made 10,000 permutations to estimate the significance of the partial Mantel correlations. All analyses were performed in R software Version 2.14.1 (R Development Core Team 2011).

\section{Results}

The number of flowers, fruits and seeds was similar in rosettes of different sizes (diameter, basal leaf and biomass). Rosettes with higher biomass produced larger inflorescences (Tab. 1). Rosettes with more flowers produced more fruits (Tab. 1).

Higher clonality decreased flower production since rosettes within plants with more rosettes produced fewer flowers $(r 2=0.51 ; F 1,18=21.02 ; P=0.0002$; Fig. $1 \mathrm{~A}$ ). The number of fruits produced by a rosette, controlled for the number of flowers, as well as the number of seeds produced by a fruit, was similar in plants with different numbers of rosettes $(r 2=0.09 ; F 1,18=2.84 ; P=0.1091 ;$ Fig. $1 B ; r 2=$ $-0.02 ; F 1,18=0.47 ; P=0.5034$, respectively).

Plants with similar number of rosettes, and similar diameter, basal leaf length, and dry biomass weight (i.e. vegetative traits) did not show spatial autocorrelation $\left(\mathrm{r}_{\text {Mantel }}\right.$ $=0.0153 ; P=0.3997)$. On the other hand, plants with similar reproductive traits - rosettes with a similar number of flowers, fruits, and seeds - were found growing closer to each other, because those reproductive traits of $V$. carinata were 
Table 1. Partial correlations ( $r$ ) between vegetative traits (rosette diameter, basal leaf length, dry biomass) and reproductive traits (number of flowers, fruits and logarithm of the number of seeds and inflorescence length). P-values in parentheses. Bold for $\mathrm{P}<0.05$.

\begin{tabular}{|l|c|c|c|}
\hline & Number of flowers & Number of fruits & Logarithm of the number of seeds \\
\hline Number of fruits & $\begin{array}{c}\mathbf{0 . 7 0 6 7} \\
\mathbf{( 0 . 0 0 6 9 )}\end{array}$ & & \\
& 0.2771 & -0.4578 \\
& $(0.3594)$ & $(0.1157)$ & -0.0313 \\
\hline Number of seeds (log) & -0.2154 & 0.0359 & $(0.9191)$ \\
\hline Inflorescence length & $(0.4797)$ & $(0.9073)$ & -0.0737 \\
\hline Diameter & -0.2661 & 0.3228 & $(0.8109)$ \\
\hline Basal leaf length & $(0.3795)$ & $(0.282)$ & -0.0307 \\
\hline Dry biomass & 0.0243 & -0.0729 & $(0.3383$ \\
\hline & $(0.9372)$ & $(0.8129)$ & $(0.9207)$ \\
\hline
\end{tabular}
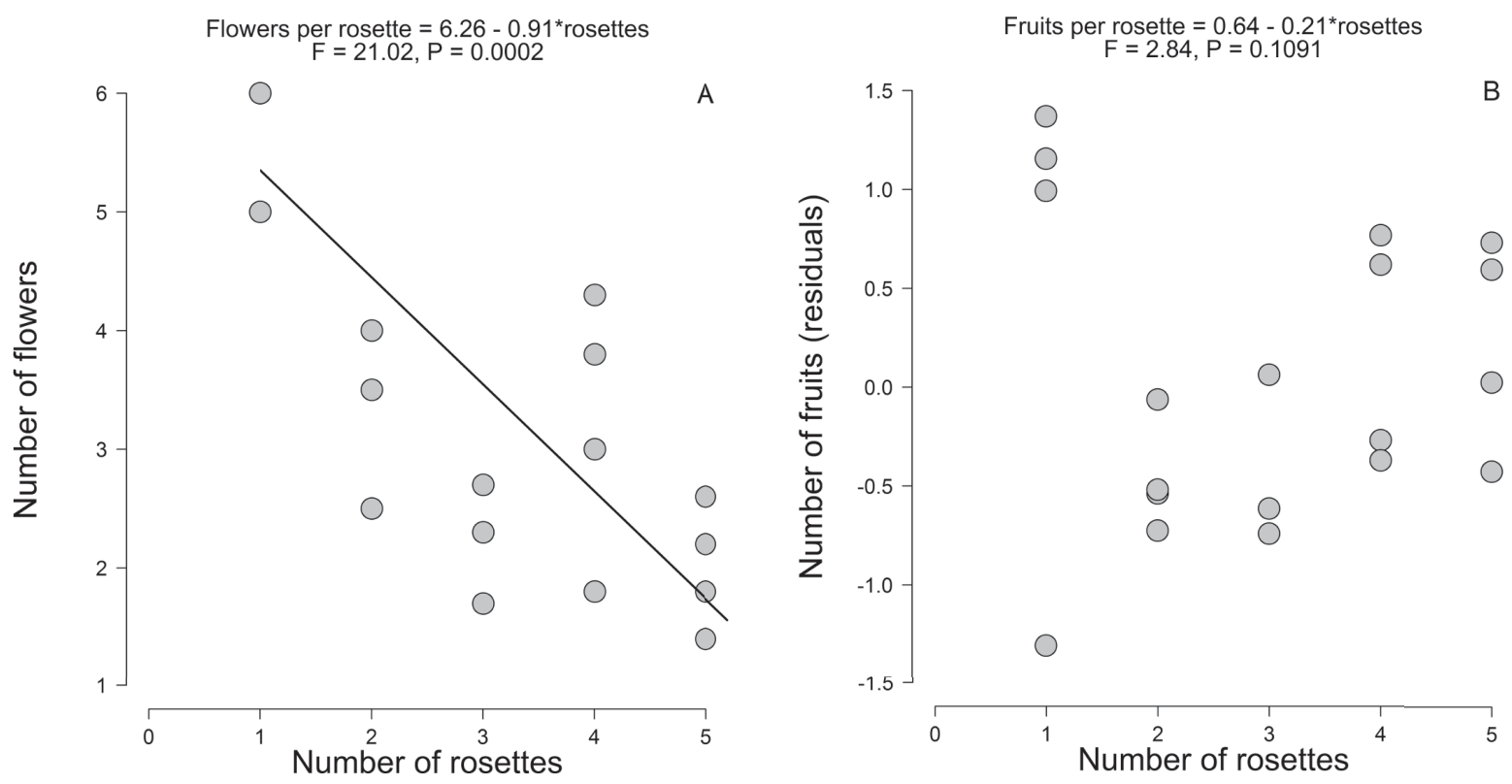

Figure 1. Relationship between reproductive traits: (A) number of flowers and (B) number of fruits (residuals) in the bromeliad Vriesea carinata as a function of the number of rosettes, RNSM.

spatially autocorrelated. The autocorrelation on reproductive traits was independent of plant size distribution ( $\mathrm{r}_{\text {Mantel partial }}$ $=0,1314 ; P=0.0312$ ).

\section{Discussion}

The reproduction of Vriesea carinata was influenced by clonality. Plants with stronger clonal growth (larger number of rosettes) produced fewer flowers per rosette, but the fruit set per flower was the same among plants with different clonal growth. On the other hand, there was no relationship between reproductive effort and rosette size or biomass. In $V$. carinata there was a spatial correlation between reproductive traits regardless of vegetative traits.

In $V$. carinata the number of fruits was related to the number of flowers produced by the rosette, but not to size or biomass. Bigger plants do not result in higher reproductive effort even when biomass was measured with inflorescences. The reproductive effort in $V$. carinata differs from what has been reported for other species, because flower production is frequently correlated with plant size, which usually increases with increased resource availability (Ågren et al. 2008; Dauber et al. 2010). In bromeliads, sexual reproduction tends to increase with an increase in plant size (Benzing 1981; Hietz et al. 2002; Mondragón et al. 2004; Mantovani \& Iglesias 2009). For V. carinata, factors such as the clonality discussed below might be causing an increase in competition for resources and limiting the amount invested in flower production, thereby uncoupling the effect of rosette size on reproductive effort.

The negative effect of clonality on reproductive effort 
indicates a negative effect on sexual reproduction resulting from vegetative (clonal) reproduction. It is usually considered that there is a positive relationship between resource availability and the conversion of those resources into vegetative growth and finally into reproduction (Bazzaz et al. 1987). In this case, resource transfer to younger rosettes would enhance flower and fruit production. Nevertheless, physiological integration between ramets and clonal plants under a more uniform environment may have a negative effect on offspring biomass (Alpert 1999); this could explain why higher clonal growth results in decreased investment in flower production in V. carinata. Furthermore, when conditions are not favorable for sexual reproduction, clonal reproduction provides reproductive assurance (Vallejo-Marín \& O'Brien 2007; Coelho et al. 2008b) and the maintenance of plant populations. In general, the persistence of clonal plants in the long term depends on a balance between the survival of genets through clonal growth after population establishment and recruitment through sexual reproduction (Jacquemyn et al. 2006).

The absence of spatial structure in the distribution of plants sharing the same vegetative traits indicates that plants more distantly located have more similar vegetative traits (related to size) than those growing closer. This may be due to the uniform environment where the plants are growing or to the physiological integration of clones buffering the negative effects of microhabitats (Roiloa et al. 2010), and resulting in similar-sized plants despite spatial/environmental variation. On the other hand, $V$. carinata has spatial structure associated with reproduction, since plants close to each other were similar in terms of number of flowers, fruits and seeds. This may be a result of spatial structuring of the environment in which the plants grow, in terms of humidity, substrate and light availability, since local abiotic conditions are usually involved with variation in reproductive efforts (Ågren et al. 2008). Even small variation in tree crowns due to light availability may change the number of flowers produced by a plant (Maia et al. 2013). Indeed, Aechmea distichantha bromeliads growing under sunny conditions had a larger reproductive effort than those in shaded conditions, when controlled for bromeliad size (Scrok \& Varassin 2011). It is also possible that aggregated individuals are genetically more closely related (Lovett-Dust 1981; Izquierdo \& Piñero 1998; Canela \& Sazima 2003; Jacquemyn \& Honnay 2008) and thus have the same reproductive potential. Plant spatial distribution can also change the patterns of pollen distribution, and closer conspecific plants have been found to have higher pollen load and higher seed set (Brys \& Jacquemyn 2010). On the other hand, for clonal plants, intensive clonal growth should increase self-pollen deposition and consequently should reduce the chance of cross-fecundation, decreasing female fecundity (Clark-Tapia et al. 2005; 2006; Dorken \& Drunen 2010). Both situations would result in similar fruit/ seed production in plants growing closer to each other.
Hence, $V$. carinata rosettes within clones with more rosettes set fewer flowers. On the other hand, rosettes with more flowers set proportionally the same amount of fruits as rosettes with fewer flowers. Plants growing closer to each other have similar reproductive efforts and this spatial distribution was independent of vegetative traits. Indeed, bromeliad size had no effect on reproductive effort, and thus spatial structure of vegetative and reproductive traits we not correlated. In Vriesea carinata, the main drivers of reproductive effort are clonality, which decreases flower production per rosette, and spatial factors, which result in greater similarity of reproductive efforts among closer plants.

\section{Acknowledgments}

We thank the Fundação Grupo Boticário de Proteção à Natureza for the support, Eros Amaral and the staff of Reserva Natural Salto Morato for the help in fieldwork, and Sheila Maris for helping with data collection.

\section{References}

Aarssen LW, Taylor DR. 1992. Fecundity allocation in herbaceous plants. Oikos 65: 225-232.

Abrahamson W, Caswell H. 1982. On the comparative allocation of biomass, energy and nutrients in plants. Ecology 63: 982-991.

Ågren J, Ehrlén J, Solbreck C. 2008. Spatio-temporal variation in fruit production and seed predation in a perennial herb influenced by habitat quality and population size. Journal of Ecology 96: 334-345.

Alpert P. 1999. Clonal integration in Fragaria chiloensis differs between populations: ramets from grassland are selfish. Oecologia 120: 69-76.

Araújo AC, Fischer EA, Sazima M. 1994. Floração sequencial e polinização de Vriesea (Bromeliaceae) na região de Juréia, sudeste do Brasil. Revista Brasileira de Botânica 17: 113-118.

Bazzaz FA. 1997. Allocation of resources in plants: state of the science and critical questions. In: Bazzaz FA, Grace J. (eds.) Plant resource allocation. California, San Diego Academic Press. p. 1-37.

Bazzaz FA, Chiariello NR, Coley PD, Pitelka LF. 1987. Allocating resources to reproduction and defense. BioScience 37: 58-67.

Benzing DH. 1981. The population dynamics of Tillandsia circinnata (Bromeliaceae) cypress crown colonies in southern Florida. Selbyana 5: 256-263.

Benzing DH. 2000. Bromeliaceae: profile of an adaptative radiation. Cambridge, Cambridge University Press.

Brys R, Jacquemyn H. 2010. Floral display size and spatial distribution of potential mates affect pollen deposition and female reproductive success in distylous Pulmonaria officinalis (Boraginaceae). Plant Biology 597-603.

Canela MBF, Sazima M. 2003. Aechmea pectinata: a hummingbird-dependent bromeliad with inconspicuous flowers from the rainforest in southeastern Brazil. Annals of Botany 92: 731-737.

Clark-Tapia R, Mandujano MC, Valverde T, Mendoza A, Molina-Freaner F. 2005. How important is clonal recruitment for population maintenance in rare plant species? The case of the narrow endemic cactus, Stenocereus eruca, in Baja California, México. Biological Conservation 124: 123-132.

Clark-Tapia R, Corrado CA, Mandujano MC, Molina-Freaner F. 2006. Reproductive consequences of clonal growth in Stenocereus eruca, a rare clonal cactus of the Sonoran desert. Evolutionary Ecology 20: 131-142.

Coelho FF, Capelo C, Ribeiro LC, Figueira JEC. 2008a. Reproductive modes in Leiothrix (Eriocaulaceae) in South-eastern Brazil: the role of microenvironment heterogeneity. Annals of Botany 101: 353-360. 
Coelho FF, Capelo C, Figueira JEC. 2008b. Seedlings and ramets recruitment in two rhizomatous species of rupestrian grasslands: Leiothrix curvifolia var. lanugiosa and Leiothrix crassifolia (Eriocaulaceae). Flora: 152-161.

Cogliatti-Carvalho L, Freitas AFN, Rocha CFD, Sluys MV. 2001. Variação na estrutura e na composição de Bromeliaceae em cinco zonas de restinga no Parque Nacional da Restinga de Jurubatiba, Macaé, RJ. Revista Brasileira de Botânica 24: 31-57.

Costa AF, Gomes-da-Silva J, Wandeley MGL. 2014. Vriesea (Bromeliaceae, Tillandsioideae): taxonomic history, and morphology of the Brazilian lineage. The Journal of the Torrey Botanical Society 141: 338-352.

Costa AF, Gomes-da-Silva J, Wandeley MGL. 2015. Vriesea (Bromeliaceae, Tillandsioideae): a cladistic analysis of eastern Brazilian species based on morphological characters. Rodriguésia 66: 429-440.

Cottenie K. 2005. Integrating environmental and spatial processes in ecological community dynamics. Ecology Letters 8: 1175-1182.

Dauber J, Biesmeijer JC, Gabriel D, et al. 2010. Effects of patch size and density on flower visitation and seed set of wild plants: a pan-European approach. Journal of Ecology 98: 188-196.

Demetrio GR, Coelho FF, Barbosa MEA. 2014. Body size and clonality consequences for sexual reproduction in a perennial herb of Brazilian rupestrian grasslands. Brazilian Journal of Biology 74: 744-749.

Dorken ME, Drunen WE. 2010. Sex allocation in clonal plants: might clonal expansion enhance fitness gains through male function? Evolutionary Ecology 24: 1463-1447.

FGBPN - Fundação Grupo Boticário de Proteção à Natureza. 2011. Curitiba, Plano de Manejo da Reserva Natural Salto Morato.

Forzza RC, Costa A, Siqueira Filho JA, et al. 2016. Bromeliaceae in Lista de Espécies da Flora do Brasil. Jardim Botânico do Rio de Janeiro. <http:// floradobrasil.jbrj.gov.br/jabot/floradobrasil/FB6441>. 18 Jan. 2016.

Givnish TJ, Barfuss MHJ, Ee B, et al. 2014. Adaptive radiation, correlated and contingent evolution, and net species diversification in Bromeliaceae. Molecular Phylogenetics and Evolution 71: 55-78.

Grindeland JM, Sletvold N, Ims RA. 2005. Effects of floral display size and plant density on pollinator visitation rate in a natural population of Digitalis purpurea. Functional Ecology 19: 383-390.

Hietz P, Ausserer J, Schindler G. 2002. Growth, maturation and survival of epiphytic bromeliads in a Mexican humid montane forest. Journal of Tropical Ecology 18: 177-191.

Izquierdo IY, Piñero D. 1998. Allozyme divergence among four species of Podaechmea s.1. and the status of Ursulaea (Bromeliaceae, Bromelioideae). Plant Systematics and Evolution 213: 207-215.

Jacquemyn H, Brys R, Honnay O, Hermy M, Roldán-Ruiz I. 2006. Sexual reproduction, clonal diversity and genetic differentiation in patchily distributed populations of the temperate forest herb Paris quadrifolia (Trilliaceae). Oecologia 147: 434-497.

Jacquemyn H, Honnay O. 2008. Mating system evolution under strong clonality: towards self-compatibility or self-incompatibility? Evolutionary Ecology 22: 483-486.

Kaehler M, Varassin IG, Goldenberg R. 2005. Polinização em uma comunidade de bromélias em Floresta Atlântica Alto-montana no Estado do Paraná, Brasil. Revista Brasileira de Botânica 28: 219-228.

Kittelson PM, Maron JL. 2000. Outcrossing rate and inbreeding depression in the perennial yellow bush lupine, Lupinus arboreus (Fabaceae). American Journal of Botany 87: 652-660.

Legendre P, Fortin M-J. 1989. Spatial pattern and ecological analysis. Vegetatio 80: 107-138.

Lovett-Doust L. 1981. Population dynamics and local specialisation in a clonal perennial (Ranunculus repens). I. The dynamics of ramets in contrasting habitats. Journal of Ecology 69: 743-755.

Machado CG, Semir, J. 2006. Fenologia da floração e biologia floral de bromeliáceas ornitófilas de uma área da Mata Atlântica do Sudeste brasileiro. Revista Brasileira de Botânica 29: 163-174.

Maia FR, Malucelli TS, Varassin IG. 2013. Ecological factors affecting the fruiting success of a Tibouchina trichopoda (DC.) Baill. (Melastomataceae) flower. Acta Botanica Brasilica 27: 142-146.
Mantel N. 1967. The detection of disease clustering and a generalized regression approach. Cancer Research 27: 209-220.

Mantovani A, Iglesias RR. 2009. Size-dependent allocation of biomass to ancillary versus flowers of the inflorescences of the epiphyte Tillandsia stricta Soland (Bromeliaceae). Acta Botanica Brasilica 23: 130-131.

Martinelli G. 1997. Biologia reprodutiva de Bromeliaceae na Reserva Ecológica de Macaé de Cima. In: Lima HC, Guedes-Bruni RR. (eds.) Serra de Macaé de Cima: diversidade florística e conservação em mata atlântica. Rio de Janeiro, Instituto de Pesquisas do Jardim Botânico do Rio de Janeiro. p. 213-250.

Martinelli G, Vieira CM, González M, et al. 2008. Bromeliaceae da Mata Atlântica brasileira: lista de espécies, distribuição e conservação. Rodriguésia 59: 209-258.

Mondragón D, Durán R, Ramírez I, Valverde T. 2004. Temporal variation in the demography of the clonal epiphyte Tillandsia brachycaulos (Bromeliaceae) in the Yucatán Peninsula, Mexico. Journal of Tropical Ecology 20: 189-200.

Piacentini VQ, Varassin IG. 2007. Interaction network and the relationships between bromeliads and hummingbirds in an area of secondary Atlantic rain forest in southern Brazil. Journal Tropical Ecology 23: 663-667.

Pitelka LF, Ashmun JW. 1985. Physiology and integration of ramets in clonal plants. In: Jackson JBC, Buss LW, Cook RR. (eds). Population biology and evolution of clonal organisms. New Haven, Yale University Press. p. 339-437.

R Development Core Team. 2011. R: A language and environment for statistical computing. Vienna, R Foundation for Statistical Computing. <http://R-project.org/>. 06 Nov. 2012.

Reitz R. 1983. Bromeliáceas e a malária-bromélia endêmica. Itajaí, Flora Ilustrada Catarinense.

Roiloa SR, Rodríguez-Echeverría S, Peña E, Freitas H. 2010. Physiological integration increases the survival and growth of the clonal invader Carpobrotus edulis. Biological Invasions 12: 1815-1823.

Sampaio MC, Perissé LE, Oliveira GA, Rios RI. 2002. The contrasting clonal architecture of two bromeliads from sandy coastal plains in Brazil. Flora 197: 443-451.

Sazima I, Buzato S, Sazima M. 1995a. The saw-billed Hermit Ramphodon naevius and its flowers in southeastern Brazil. Journal für Ornithologie 136: 195-206.

Sazima M, Buzato S, Sazima I. 1995b. Polinização de Vriesea por morcegos no sudeste brasileiro. Bromelia 2: 29-37.

Sazima I, Buzato S, Sazima M. 1996. An assemblage of hummingbirdpollinated flowers in a montane forest in southeastern Brazil. Botanica Acta 109: 149-160.

Sazima M, Buzato S, Sazima I. 1999. Bat-pollinated flower assemblages and bat visitors at two Atlantic forest sites in Brazil. Annals of Botany 83: 705-712.

Scrok GJ, Varassin IG. 2011. Reproductive biology and pollination of Aechmea distichantha Lem. (Bromeliaceae). Acta Botanica Brasilica 25: 571-576.

Smith LB, Downs RJ. 1977. Tillandsioideae (Bromeliaceae). In: Smith LB, Downs RJ. (eds.) Flora Neotropica. New York, Hafner Press. p. 663-1492.

Vallejo-Marín M, O‘Brien HE. 2007. Correlated evolution of selfincompatibility and clonal reproduction in Solanum (Solanaceae). The New Phytologist 173: 415-421.

Varassin IG, Sazima M. 2012. Spatial heterogeneity and the distribution of bromeliad pollinators in the Atlantic Forest. Acta Oecologica 43: 104-112.

Wanderley MGL, Martins SE. 2007. Bromeliaceae. In: Wanderley MGL, Shepherd GJ, Melhem TS, Giulietti AM. (eds.) Flora fanerogâmica do estado de São Paulo. São Paulo, Instituto de Botânica. p. 39-161. 